\title{
Johns Hopkins leads the field in university military research
}

\section{Washington}

THE continuing campus debate on President Reagan's Strategic Defense Initiative (SDI) has again forced US universities into the political spotlight over their attitudes towards military research. Although some have been at pains to distance themselves from the programme, critics are using the SDI controversy to attract attention to all university military research, an activity universities are not anxious to publicize. The Applied Physics Laboratory (APL) of Johns Hopkins University, in suburban Maryland about 20 miles from Washington, has the biggest university military research budget in the country.

With its innocuous-sounding name and studied low profile, APL has managed to avert much of the political controversy that has beset other university military laboratories, even though 85 per cent of its funding is from the Navy and its staff of more than 3,000 dwarfs the university's main academic campus in Baltimore.

APL spokesmen point out that the laboratory does no work on actual

\section{India's liberalized software policy $\$ 22$ \\ Bangalore}

INDIA has developed a new policy on the development of computer software aimed at capturing a larger share of the booming global market. The strategy will allow drastic reduction of import duty, single clearance of applications from software exporters and liberal foreign exchange for manpower training. To give a boost to software development, four Indian institutes of informaties will be created which will focus on software education. Similarly, the government will support private institutions in their training computer software manpower. "We must train 10,000 software specialist: every year", says Mr Narayanan, Union Minister of State for Science and Technology. Duty restrictions for the import of software have been relaxed, although the importers must have some export plans.

The policy lays down that software development for the domestic market would be permitted to wholly Indian companies and companies having foreign equity up to 40 per cent; companies with foreign equity exceeding 40 per cent will be allowed to be created for 100 per cent export of software.

India wants a larger share of the projected US\$100,000-million-a-year world software market by 1990 . The immediate target is exports of the order of US\$300 million, constituting 0.6 per cent of the international trade. Radhakrishna Rao weapons, but rather on guidance systems for missiles, some of which may be nuclear. The protesters, they say, are anti-nuclear activists not associated with the university.

The protesters' main complaint is that APL's work on guidance systems has led to the development of first-strike nuclear weapons. Although APL director Dr Carl Bostrom acknowledges the importance of the strategic debate, he says it is not part of the laboratory's charter to analyse strategy. But Bostrom, a space plasma physicist by background, treads carefully on SDI, and says he is sensitive to the controversy. Directors of some other major laboratories performing SDI research have been wary about accepting large amounts of SDI money because of the political volatility of the programme, and because the new Democratically controlled Senate will probably slow the pace of SDI research; Bostrom points out that he has no advance knowledge. Only about 7 per cent of APL's $\$ 333$ million budget is spent on in-house SDI work, he says.

Much of that was from a single SDI experimental Delta payload scheduled for launch next year. When the SDI kinetic energy weapons division approached APL for 'advice' on the multi-purpose payload, Bostrom is at pains to explain, APL reviewed the proposal in-house to make sure of its scientific merit before agreeing to help. SDI aside, even researchers who accept the need for work on missile guidance systems, for example, disagree over whether the university should continue to manage APL. Part of the reason is its isolation from academic life. Robert Park of the American Physical Society says the isolation makes it hard to evaluate APL's academic contributions.

APL does collaborate with other university departments, especially in biomedicine, but such collaboration seems to be the exception; about 50 per cent of the laboratory's work is classified. Dr Paul Feldman of the university's department of physics and astronomy worked with APL engineers on the Johns Hopkins Ultraviolet Telescope, a major observatory now scheduled for launch in 1988 , but says such cooperation is rare.

Dr Harold A. Weaver, assistant project scientist on the telescope, agrees, saying he opposes APL's connection with the university because of its role as a defence contractor; he believes that APL is dominated by secrecy. But others value the APL link; Dr Charles R. Westgate of the engineering department has students who work at APL and has APL staff studying in his department.

So why does the university continue to sustain its relationship with a laboratory with which the main academic campus has, in the view of some researchers, about as much in common as with its division in China? Benefits can be seen for both sides; researchers are not tied to military pay scales, and can enjoy benefits such as temporary campus fellowships and cheap tuition for spouses and children. University president Dr Steven Muller maintains that the atmosphere is academic rather than military and emphatically rejects the suggestion that Hopkins continues to

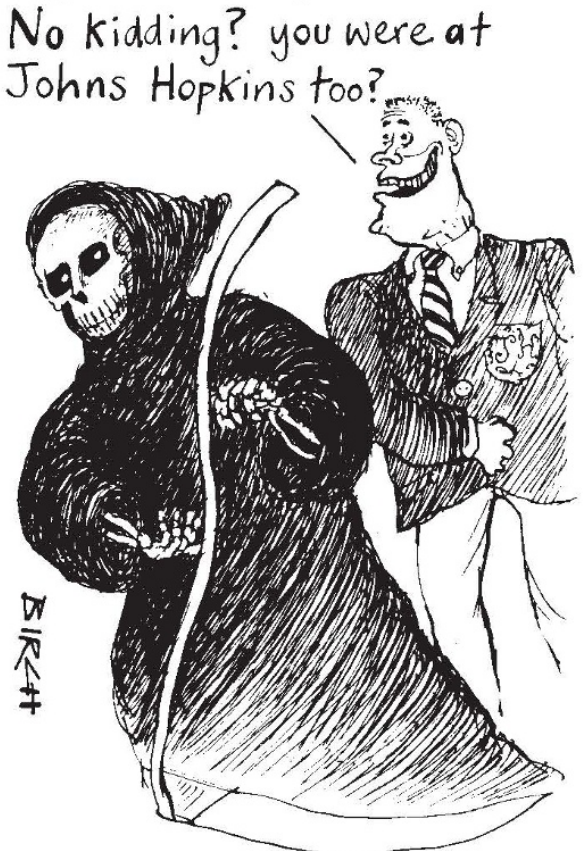

nurse APL because of the financial benefits, which amount, he says, only to a modest $\$ 150,000$ annual management fee from the defence department, plus interest from a $\$ 30$ million reserve fund established to provide the university's insurance should the Pentagon pull out.

Bostrom points out that the laboratory benefits the university by providing teaching for university evening classes and research opportunities for graduate students. Its Eisenhower research centre, which performs unclassified basic research published in the open literature, is highly regarded (although director Dr Ted Poehler admits that basic researchers are the "poor relations" at APL, and find it harder to get money than those who work on missiles). And Bostrom is forthright about the laboratory's continuing reliance on military support: it fulfils an essential role in keeping the peace by providing an independent assessment of Navy research.

Muller says that although APL's applied work cannot be evaluated by normal academic criteria, it performs an "extraordinary public service" that a university can be well justified by being associated with. Protesters or no, APL seems set to continue in its role as the Navy's hightechnology research base for the foreseeable future.

Tim Beardsley 